\title{
POTENCIAIS PROBLEMAS DE MOBILIDADE URBANA DIÁRIA RELACIONADOS A INUNDAÇÕES NO RIO DE JANEIRO (BRASIL)
}

\author{
Leonardo Bacelar Lima Santos ${ }^{1}$ \\ Luciana de Resende Londe ${ }^{2}$ \\ Érico Soriano ${ }^{3}$ \\ Aurelienne Aparecida Souza Jorge ${ }^{4}$ \\ Andreza Fogaça Coelho ${ }^{5}$
}

\begin{abstract}
Resumo A estimativa de pessoas que passam por zonas de tráfego, juntamente com informações hidrográficas, serve como base para o estudo de relações entre mobilidade $e$ inundações. A partir de dados de origem e destino, foi desenvolvido um script baseado no Google Maps para obter os caminhos feitos em cada viagem. Para computar a quantidade de pessoas diretamente afetadas na mobilidade, foram selecionadas todas as regiões interceptadas pelos rios. O número total de pessoas indiretamente afetadas foi calculado através da análise de rotas que interceptam os rios, e, com base nesta informação, foram estimadas quantas pessoas têm sua mobilidade potencialmente afetada por inundações em cada rio. Os resultados sugerem que os rios Pavuna e Guandu Mirim devem receber atenção prioritária por tomadores de decisão para mitigar os efeitos de inundações sobre a mobilidade urbana na região metropolitana do Rio de Janeiro.
\end{abstract}

Palavras-chave: Desastres Naturais; Vulnerabilidade; Matriz de Origem-Destino; Postgis.

\section{POTENTIAL FLOOD-RELATED DAILY URBAN MOBILITY PROBLEMS IN RIO DE JANEIRO}

(BRAZIL)

Abstract: Unplanned urban expansion merges mobility and flood problems, creating a new challenge to be faced by big cities stakeholders. It is known that transport and mobility

1. Físico, doutor em Computação Aplicada pelo Instituto Nacional de Pesquisas Espaciais (INPE). Pesquisador Adjunto do Centro Nacional de Monitoramento e Alertas de Desastres Naturais (Cemaden - MCTI), (santoslbl@gmail.com).

2. Bióloga, doutora em Sensoriamento Remoto pelo Instituto Nacional de Pesquisas Espaciais (INPE). Pesquisadora Adjunta do Centro Nacional de Monitoramento e Alertas de Desastres Naturais (Cemaden MCTI), (luciana.londe@cemaden.gov.br).

3. Geógrafo, doutor em Ciências da Engenharia Ambiental pela Escola de Engenharia de São Carlos da Universidade de São Paulo. Pós-doutorando FAPESP pela Universidade Federal de São Carlos, (ericogeo@gmail.com).

4. Cientista da Computação, especialista em Tecnologias e Sistemas de Informação. Analista de Informática do Centro Nacional de Monitoramento e Alertas de Desastres Naturais (Cemaden - MCTI), (aurelienne.souza@cemaden.gov.br).

5. Cientista da Computação, especialista em MBA em Gestão Estratégica de Negócios. Tecnologias e Sistemas de Informação. Analista de Informática do Centro Nacional de Monitoramento e Alertas de Desastres Naturais (Cemaden - MCTI), (andreza.fogaca@gmail.com). 
activities cause impacts on urban environment. Nevertheless, natural phenomena may also cause impacts on urban mobility. The estimate of the flow of people among traffic regions, together with hydrographic information, support the computation of people affected during flood episodes. Rio de Janeiro State registers the highest urbanization rate in Brazil. Based on origin and destination data, a Google Maps based script was developed to get each travel path. All regions intercepted by local rivers were considered to compute the amount of people directly affected in their mobility. The total number of indirectly affected people is calculated through the routes that intersect each river. The results suggest that Pavuna and Guandu Mirim Rivers should be highly considered by stakeholders to mitigate flood effects on urban mobility in the MRRJ.

Key words: Natural Disasters; Vulnerability; Origin-Destination; PostGIS.

\section{INTRODUCTION}

Urban population is growing worldwide. In 2010, more than half of global population (51\%) was living in urban spaces. Projections foresee $65 \%$ of global population in urban environments in 2045 (UN, 2011). In Latin America, 90\% of the population from Brazil, Argentina, Chile, Paraguay and Uruguay will be living in municipalities in 2020 (CEPAL, 2012). Nowadays, Latin America and Caribbean are the most urbanized region in world (80\%).

Projections highlight the increase of population density in the cities. Although countries and regions are different, they will have to face similar problems, such as pollution, urban mobility challenges, sanitation, criminality and the occupation of risk areas. Cities form risk scenario for societal, economic and environmental losses. A high population density increases the number of people affected by disasters. In Brazil, the natural characteristics were underestimated during the fast urbanization process, implying severe and complex changes in physical and biotic environments (Nobre, 2011).

Natural Disasters cause human and material losses around the world and their increasing risk is a worldwide concern. Due to its huge population and physical characteristics, Brazil is vulnerable to many natural disasters and their impacts affect thousands or even millions of people each year (Soler et al., 2013). The most frequent disasters in Brazil include mass movements, floods and flash floods. According to the "Brazilian Atlas of Natural Disasters" (CEPED, 2011), from 1991 to 2010, 50\% of disasters occurrences correspond to flashfloods and floods. 
Most of South America cities lack legislation to avoid the occupation of flooding risk areas, rising, therefore, risks of urban floods (Tucci, 2003). Soil waterproofing and increased surface runoff induce urban floods. In Brazil, floods and flashfloods sum $21 \%$ of total number of disasters. These processes caused 1106 victims in the country and 580 deaths (52\%) in the Southeast region (CEPED-UFSC, 2012). Flashfloods are responsible for $12 \%$ of natural disasters in Brazil, mainly in the Southeast region. Rio de Janeiro state registered 195 out of 274 victims.

Unplanned urban expansion merges mobility and flood problems, forming a new challenge to be faced by big cities stakeholders.

Urban mobility is the displacement of people and goods in an urban space related to daily activities (Cui, 2006). The Brazilian law 12.587/12, article 4, about the national urban mobility guidelines, defines urban mobility as the condition in which people and freight displacement occur in urban space (Brasil, 2012). According to Brazilian Municipalities' Ministry, urban mobility represents multimodal people travels in an urban area, with any objectives (Ministério das Cidades, 2007).

As stated by Hannam, Sheller and Urry $(2006$, p.1), "Issues of movement, of too little movement or too much or of the wrong sort or at the wrong time, are central to many lives, organizations and governments".

Mobility data analysis is important to improve our understanding of complex space-time dynamics in different domains, such as urban planning, transportation, demography, and emergency management (Guo et al., 2012).

Scientific publications about people transportation often refer to migration analysis, a phenomenon characterized by other spatial and time scales. Many of them concern politics for emergency mobility during disasters occurrence, but just a small part of them addresses urban mobility as a local and daily phenomenon.

Subsequent to the increasing use of public transportation systems, Origin and Destination (OD) surveys have been developing and improving the OD estimates (Cui, 2006). Through that kind of research, it is possible to determine the spatial location of origin and destination for people travels, between traffic zones (spatial transport unit), during daily activities. 
It is known that transport and mobility activities, in any extent, cause strong impacts on the urban environment, generating pollutants emission and traffic jams (prompt impacts) and inducing economic and urban development (secondary impacts). Nevertheless, natural phenomena may also cause serious impacts on urban mobility.

According to Hunter (2005):

Migration as a demographic process can be associated with environmental hazards in several ways. On the one hand, proximate environmental hazards might influence residential decision-making by shaping the desirability of particular locales. In this case, we might consider environmental hazards as factors shaping migration.

Considering social and economic impacts of climate change, Gray and Mueller (2012) emphasize the potential displacement of large numbers of involuntary migrants. Accordingly, UNHCR (2009) mention that human mobility and displacement will undoubtedly suffer changes in their scale and complexity as a result of climate change and multiple natural disasters.

Hogan and Marandola Jr. (2007) considered the relationship established between the population mobility and vulnerability and responses to hazard. They assert that people tend to leave disaster-prone areas and move to more secure places when it is possible to move nearby or in the same municipality. The authors also consider the daily travel from home to work and the handlings to avoid risk areas:

Municipalities will have a specific role concerning this matter. Cities are the most vulnerable spaces, with a concentrated population (high density) and disrespect for the natural place and natural phenomena (Hogan and Marandola, 2007, p.83).

According to Marandola Jr. (2006, p.4) "when we think about individuals, families or even specific areas and the rise of risks and dangers, mobility is one of the most important phenomena affecting hazard spread and the characterization of different vulnerabilities".

The vulnerability of roads and large mobility areas performs a dynamic process, as described by Veyret $(2007, \mathrm{p} .43)$ : 
Vulnerability varies both in space and time, especially in the cities, because of pendulum migrations. Consequences of December, 26th 1999 storm in Paris would be much more serious if it had happened during a working day, instead of the Sunday morning after Christmas. If it was a normal working day, roads would have a higher traffic, streets would be much more crowded and people would be at schools or other public buildings instead of their own homes. Once this dynamic nature of mobility processes is well known, it is possible to produce vulnerability maps by time slots, as those in a thesis, about the city of Nimes (Legeard, 2000 apud Veyret, 2007), that establish the following slots:

- Daily Vulnerability: commercial period, except for peak hours;

- Peak Vulnerability: period of hard movement in transportation net (roads, collective transportation, stations);

- Night Vulnerability: when population is concentrated in residential areas.

Legeard (2000 apud Veyret, 2007) uses a scale with three vulnerability levels matching the three time slots, calculated for each sector of the land occupation plan, according to the kind of activity. Those values refer only to individuals.

Considering the importance of mobility issues, some Governmental legislation is necessary. In Brazil, there is a specific law for urban mobility matters (Brasil, 2012). It establishes the national System for Urban Mobility, the organized group of ways of transportation, services and infrastructures to ensure the displacement of people and freight in the municipalities (Article $3^{\text {rd }}$ ). The National Urban Mobility Politics emphasize the sustainable development in the cities, considering socioeconomic and environmental factors (Article $5^{\frac{\text { th }}{}}, \mathrm{II}$ ) and follow some guidelines, such as: I - integration to the Urban Development Politics and sector politics for habitation, basic sanitation, planning and management for land use and IV mitigation of environmental, societal and economic costs of people and freights displacement in the city (Article $6^{\text {th }}$ ).

The estimate of the number of people that leave, pass through and arrive at each traffic region subdivision, together with hydrographic information, support the computation of those people whose mobility is affected during flood episodes. This information may be used by different stakeholders to draw maps, analyze strategies, develop specialized planning and suggest measures to mitigate flood effects on urban mobility in a specific region. 
Pereira e Schwanen (2013), analyzing published articles about urban mobility and time and displacement variations, highlight the lack of studies focusing either on metropolitan areas or on developing countries.

In Brazil, the shift from rural to urban population happened around the 1960 decade. Brazil's population nowadays is mostly urban, with estimates of having more than $95 \%$ of its population in urban areas till 2050. Rio de Janeiro State register the highest urbanization rate in Brazil: more than $96 \%$ of its population lives in urban centers. According to Pero and Mihessen (2012, p.1): Rio de Janeiro is the most biggest metropolitan federation unit in Brazil. According to IBGE's 2010 Census, 74\% of its population (almost 12 million) lives in the Metropolitan Region of Rio de Janeiro (MRRJ), which shows an urbanization rate of more than $99 \% .55 \%$ of those people work at Rio de Janeiro municipality and there is a strong flow of people from other municipalities to the capital city, what makes urban mobility matters a key issue for development in the state.

Considering the importance of MRRJ in Brazil, we aimed to analyze travels in that region calculating the number of people both directly and indirectly affected in their mobility under flood events

\section{MATERIAL AND METHOD}

\section{Study area}

The Metropolitan Region of Rio de Janeiro (MRRJ) covers $12 \%$ of the total Rio de Janeiro's state area, with a population of $11,835,708$, and a population density of 2291.90 inhabitants $/ \mathrm{km}^{2}$ (IBGE, 2010). Its Gross Domestic Product sums up to $\mathrm{R} \$ 172.563$ billion, forming the second largest hub of the country's wealth. It concentrates $70 \%$ of the state's economic power and $8.04 \%$ of all goods and services produced in Brazil. The state's capital city, Rio de Janeiro, performs $50 \%$ of the Gross Domestic Product of the state and $53 \%$ of the population of the MRRJ (IBGE, 2010).

Displacements from home to work in Rio de Janeiro and São Paulo in 2009 were 30\% longer than the average for other Brazilian metropolitan regions (Pereira and Schwanen, 2013). 
The MRRJ, in Rio de Janeiro brazilian state (Figure 1), includes the following municipalities: Mangaratiba, Itagua, Paracambi, Seropédica, Japeri, Queimados, Nova Iguaçu, Rio de Janeiro, Mesquita, Nilópolis, Belford Roxo, São João do Meriti, Duque de Caxias, Magé, Niterói, São Gonçalo, Guapimirim, Itaboraí, Maricá e Tanguá (Figure 2). Japeri, Queimados, Belford Roxo are listed among the 10 municipalities with worst results for the index of urban well being concerning mobility (Queiroz and Ribeiro, 2013).

The MRRJ is intersected by many rivers and the regions around these rivers are predominantly urban, according to the distribution of census units (Figure 2). A census unit is the smallest land unit which is suitable for demographic data collection. The smaller a census unit is, the denser is the population in that area. Based on the Atlas of vulnerability to floods in Rio de Janeiro (ANA, 2013), the main rivers in this region, concerning frequency and impact of floods, on a 1:1.000.000 scale, are: Macaco, Guandu, GuanduMirim, Pavuna, Tinguá, Saracuruna, Guapimirim e Tanguá (Figure 2).

Flood episodes in the capital city of Rio de Janeiro are well known (Brandão, 2001). Table 1 shows registers of hydrological disasters related to each river in the other cities of MRRJ.

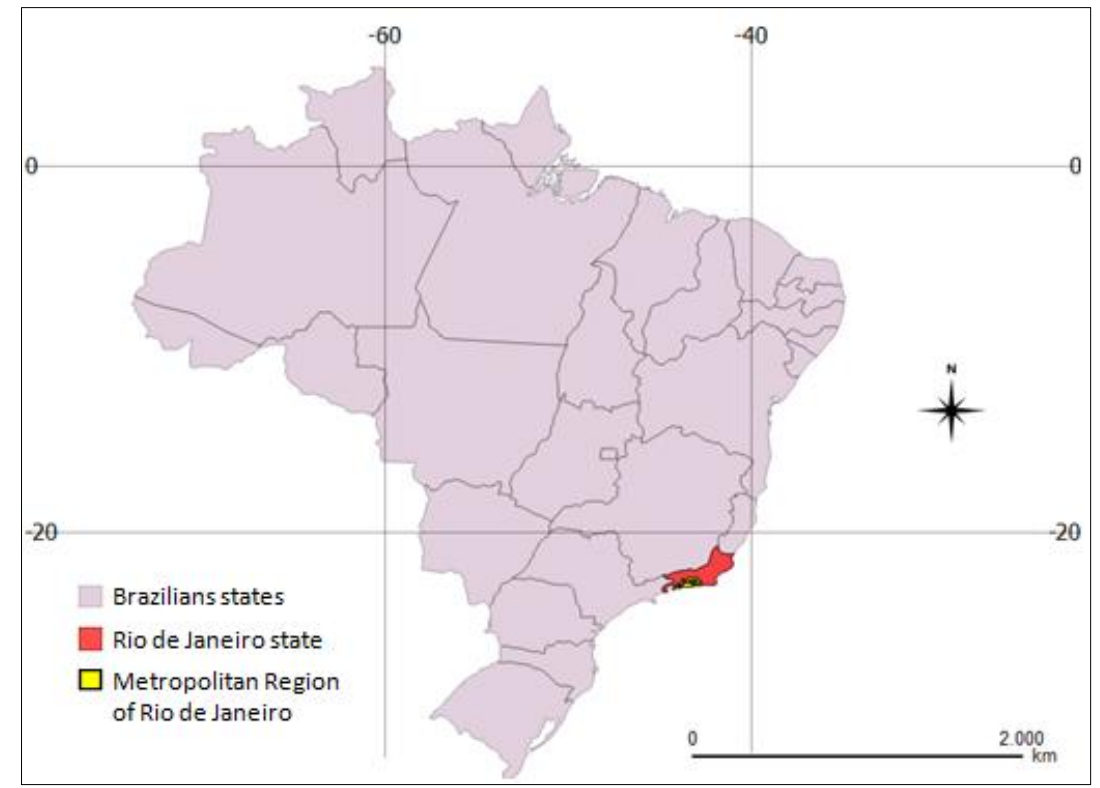

Figure 1: Map of Brazilians states highlighting Rio de Janeiro state and the Metropolitan Region of Rio de Janeiro.

Source: IBGE. Org.: the authors. 


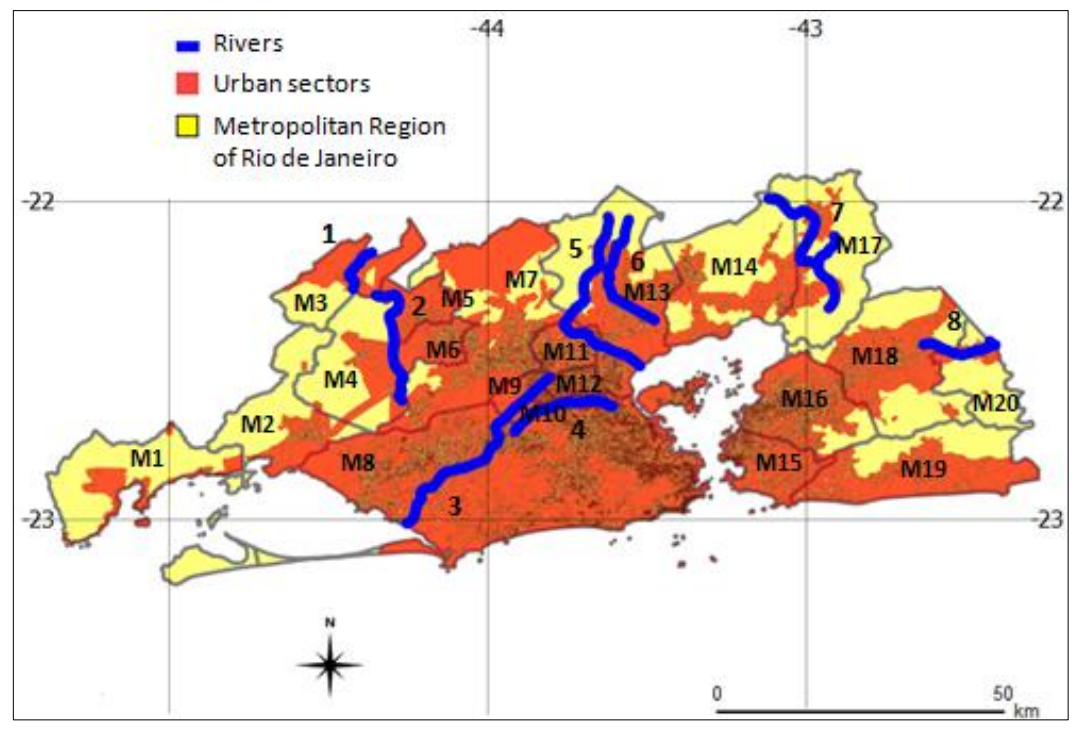

Figure 2: Municipalities (yellow polygons) and rivers (blue lines) associated to floods in the MRRJ. Red polygons with grey borders show IBGE's urban census units. According to the numbering, the MRRJ muncipalities are: M1. Mangaratiba, M2. Itagua, M3. Paracambi, M4. Seropédica, M5. Japeri, M6. Queimados, M7. Nova Iguaçu, M8. Rio de Janeiro, M9. Mesquita, M10. Nilópolis, M11. Belford Roxo, M12. São João do Meriti, M13. Duque de Caxias, M14. Magé, M15. Niterói, M16. São Gonçalo, M17. Guapimirim, M18. Itaboraí, M19. Maricá and M20. Tanguá; and the rivers are: 1. Macacos, 2. Guandu, 3. Guandu Mirim, 4. Pavuna, 5. Tinguá, 6. Saracuruna, 7. Guapimirim and 8. Tanguá. IBGE and ANA. Org.: the authors.

\begin{tabular}{|c|c|c|}
\hline MUNICIPALITY & $\begin{array}{l}\text { EPISODES OF FLASH FLOODS } \\
\text { (OCCURRENCE YEARS) }\end{array}$ & $\begin{array}{l}\text { EPISODES OF FLOODS } \\
\text { (OCCURRENCE YEARS) }\end{array}$ \\
\hline Belford Roxo & 2001, 2003(3), 2005, 2006(3), 2007,2008 & $2004,2009,2010$ \\
\hline Duque de Caxias & 2001, 2002, 2003 & $\begin{array}{r}2004,2006,2009(2) \\
2010(3)\end{array}$ \\
\hline Guapimirim & $2008,2009,2010$ & $2009(2), 2010(4)$ \\
\hline Itaboraí & 2008,2009 & $2009,2010(2)$ \\
\hline Itaguaí & 1996 & $--\cdot$ \\
\hline Japeri & --- & $2001,2003,2009,2010(2)$ \\
\hline Magé & 2004,2005 & 2001 \\
\hline Mangaratiba & 2003, 2004, 2007, 2008, 2009(2), 2010 & --- \\
\hline Maricá & 2010 & -- \\
\hline Mesquita & 2006,2010 & 2007,2009 \\
\hline Nilópolis & --- & 2009,2010 \\
\hline Niterói & $2010(2)$ & --- \\
\hline Nova Iguaçu & 2006, 2007 & --- \\
\hline Paracambi & $2001,2003,2006,2008$ & --- \\
\hline Queimados & $2009,2010(2)$ & -- \\
\hline Seropédica & --- & $2001,2006,2008,2010$ \\
\hline São Gonçalo & --- & $2009,2010(3)$ \\
\hline São João do Meriti & $1996,2003,2007,2010$ & -- \\
\hline Tanguá & 2009,2010 & 2009,2010 \\
\hline
\end{tabular}

Table 1: Episodes of floods and flash floods listed for cities on the MRRJ according to occurrence year, from 2001 to 2011.

Source: Brazilian Atlas of Natural Disasters (CEPED, 2011)

*Numbers in parenthesis refer to the amount of occurrences during that year. 


\section{Origin-Destination Data and routes}

To ease mobility studies, regions are often splitted into Traffic Zones (TZ). According to PDTU (2010), 485 TZ appeared at least once as a source or a destination in the Origin-Destination (OD) survey. The amount of travels in the region summed a sample of 112,900 travels. Travels by foot correspond to approximately $30 \%$ of all travels, while travels by car or bus represent $60 \%$ of the total of travels. The total travels between each pair of TZ were used to build the flow matrix.

To set the distance matrix, the centroid of each TZ was extracted and the Google's API $\begin{array}{llll}\text { Distance } & \text { Matrix applied. }\end{array}$ [https://developers.google.com/maps/documentation/distancematrix/?hl=eg]. Provided by origin and destination coordinates and travel mode (either driving or walking), a PHP script was developed to get each travel length.

Considering the 100 most common travels - the 100 origin \destination ordered pairs characterized by high number of users; each path was saved in KML format, based on Google Maps resources [https://www.google.com.br/maps].

\section{Data approach}

The saved paths and other data (hydrography, traffic zones, and flow matrices) were inserted into PostgreSQL, a dataset management system, together with its spatial extension, PostGIS, which allows handling with geospatial objects and making location queries. The paths' KML archives were imported to the dataset through a specific tool, which is part of a library designed to work with these kinds of archives. Shapefiles for hydrography and traffic zones were inserted into the dataset through shp2pgsql, a tool from PostGIS. A script written in Python was created to operate geometric data inside the dataset, using a specific library to accomplish the connection to PostgreSQL. The script loads the flow matrices and matches this data to hydrography, traffic zones and routes.

To compute the amount of people directly affected in their mobility, all traffic zones intercepted by local rivers were selected. Then, all people with origin or destination in one of these zones are summed up. 
The total number of indirectly affected people was calculated through the routes that intersect each river, and, based on that information, the number of people that had their mobility affected by floods on each river was computed.

\section{RESULTS AND DISCUSSION}

As economical, societal and polítical realities will undergo deep changes during the next decades, the future of megacities will depend on planning and integrated management systems (Nobre, 2011). The analysis of the main local problems is the first step towards an effective planning. Considering urban mobility, there is a need for information and understanding of the current situation and local scenario.

This paper contributes to such understanding about the MRRJ: an analysis of different characteristics of MRRJ's rivers and their impact on urban mobility provides essential data for urban planning and development to face mobility challenges. Based on the study and diagnosis of how rivers relate to mobility, decision makers are able to better define investments and actions for transport of people and goods during the following years. Applying the index developed in this work, IFUM - Impact of Floods on Urban Mobility, we can achieve some guidelines for a better planning for the region, in this case, MRRJ.

Figure 3 shows, on the map, the IFUM index for the direct approach. It was expected that Pavuna River and Guandu Mirim River showed a high IFUM index, as their flow through the city of Rio de Janeiro, where there is a high concentration of people.

Guapimirim River, despite its location on an area with few urban sectors, shows a high IFUM value. It is peculiar that Tinguá and Saracuruna rivers show different IFUM indexes, as they are close to each other. Tinguá River is bigger than Saracuruna River and it flow throw populated areas of the cities, such as Duque de Caxias (South) and Belford Roxo (North). Both cities are densely populated: Duque de Caxias with 341.304 (Censo IBGE, 2010) and Belford Roxo with 469.322 (Censo IBGE, 2010). The south region of the municipality of Duque de Caxias shows a good economic development, with many job offers; therefore it is the destination of many travels. 
Guandu Mirim River intercepts two important roads: The BR-116 road (the main highway in Brazil, with 4,385 km) and BR-101 road. Brazil Avenue is the biggest urban part of BR-101 road and links North BR-101 (Rio Niterói Bridge and Rio-Vitória/Niterói-Manilha Road) to South BR-101 (Rio-Santos Road). Brazil Avenue is also part of BR-040, BR-116 and BR-465, in other words, it is part of all national roads that pass through the city of Rio de Janeiro. Therefore, a flood process impacting this river would jeopardize mobility on the MRRJ's main circulation roads. Guandu Mirim, a lengthy river, shows a high indirect IFUM index. The other rivers show lower IFUM values due to fewer intercepted main paths.

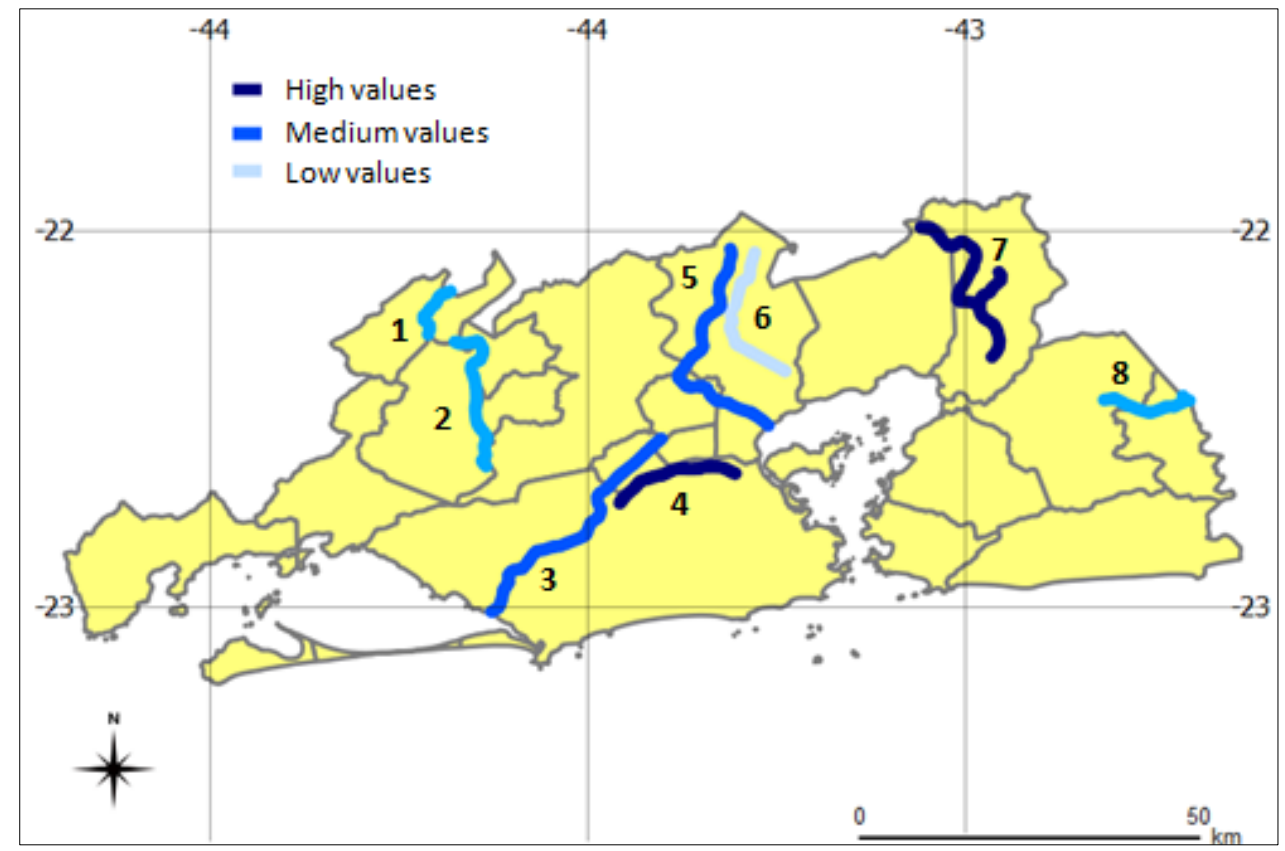

Figure 3: Illustration of IFUM index, according to direct mode: people whose origin or destination is located in traffic zones which intercept the analyzed rivers. The index values are in blue scale (highest values in dark blue); the municipalities' borders are in gray lines. The rivers are: 1. Macacos, 2. Guandu, 3. Guandu Mirim, 4. Pavuna, 5. Tinguá, 6. Saracuruna, 7. Guapimirim and 8. Tanguá. Source: IBGE and ANA. Org.: the authors.

\begin{tabular}{|l|l|l|}
\hline \multicolumn{1}{|c|}{ RIVER } & \multicolumn{1}{c|}{ IFUM } & \multicolumn{1}{c|}{ NOTES } \\
\hline Guandu Mirim River & High direct IFUM & -- \\
\hline Pavuna River & High direct IFUM & $\begin{array}{l}\text { It passes through the municipality of Rio de } \\
\text { Janeiro, including high daily mobility regions. }\end{array}$ \\
\hline Saracuruna River & Low direct IFUM & $\begin{array}{l}\text { Its upstream is in the municipality of Duque de } \\
\text { Caxias and downstream is at Baia de Guanabara. } \\
\text { Near downstream, its right margin receives the } \\
\text { "vala do Faria" what occasionally causes floods in } \\
\text { the region. }\end{array}$ \\
\hline Guapimirim River & High direct IFUM & $\begin{array}{l}\text { It flows through a residential area with high } \\
\text { population density }\end{array}$ \\
\hline
\end{tabular}

Table 2: Analysis of IFUM index (direct mode) for the main local rivers in the MRRJ. Source: The authors. 
Figure 4 shows the indirect mode of IFUM index, according to indirect mode: people whose routes intercept the analyzed rivers. The indirect component relates to the intersection between a river and a path. Rivers outside Rio de Janeiro municipality intercept few of the main paths, what means that floods in Rio de Janeiro municipality affect a high number of travels, and, consequently, a high number of people.

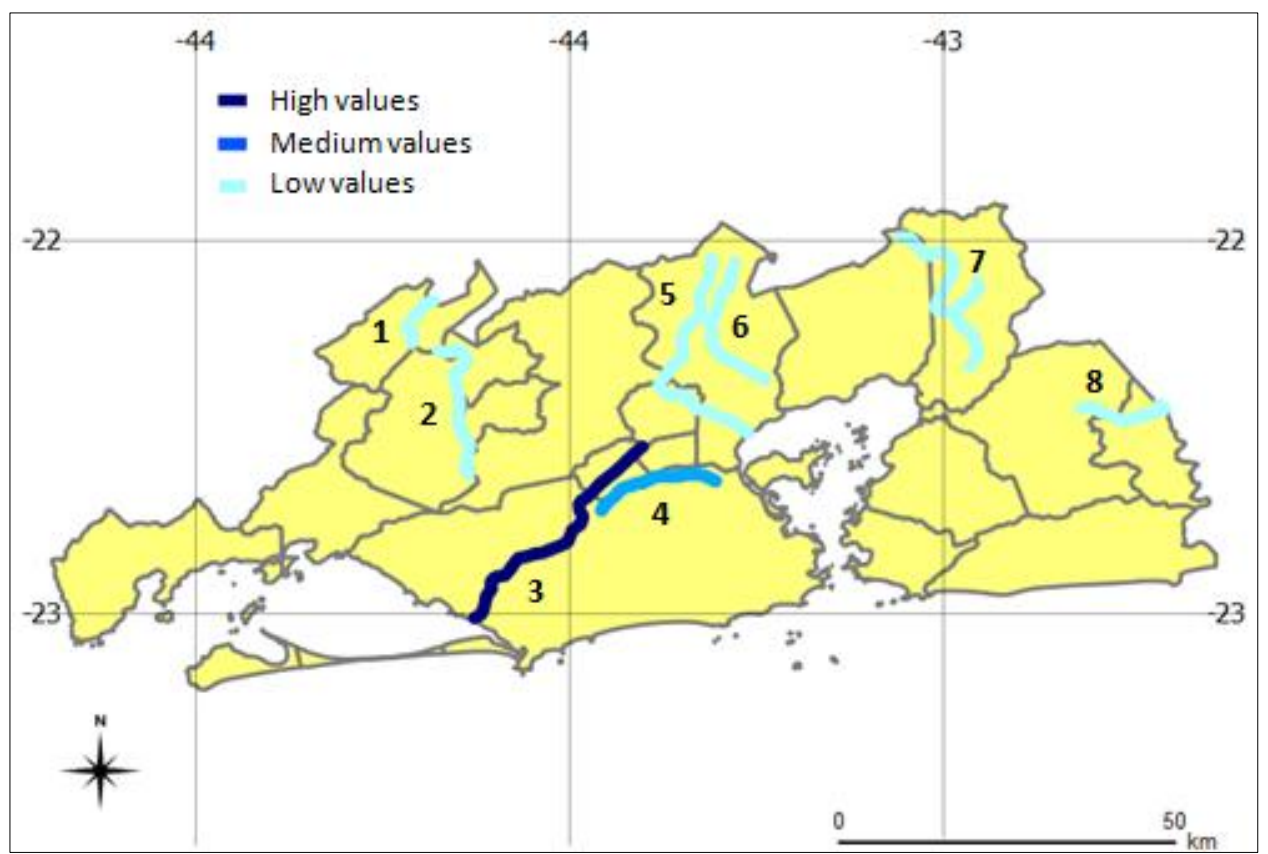

Figure 4: Illustration of IFUM index, according to indirect mode: people whose routes intercept the analyzed rivers. The index values are in blue scale (highest values in dark blue); the municipalities borders are in gray

lines. The rivers are: 1. Macacos, 2. Guandu, 3. Guandu Mirim, 4. Pavuna, 5. Tinguá, 6. Saracuruna, 7.

Guapimirim and 8. Tanguá.

Source: IBGE and ANA / Org.: the authors

Floods are also frequent in Tinguá and Saracuruna Rivers. The direct IFUM index is high for Tinguá River and low for Saracuruna River. For urban planning and management matters, Tinguá River should receive priority in relation to Saracuruna River, even though both of them show high flood frequencies.

A measurement of floods frequencies and impact was analyzed on the Atlas of vulnerability to floods in Rio de Janeiro (ANA, 2012). Flood frequencies were considered high when there are floods in a period of 5 years or less, medium when they happen from 5 to 10 years and low when they happen in a period longer than 10 years. It is noticeable that floods are frequent in Guapimirim River. According to Figures 3 and 4, Guapimirim River shows a high IFUM index, implying that it is a problematic region. A high impact would means high risk to 
human life and substantial harm to main services, installations and infra-structure works; medium impacts are characterized by reasonable harm to main services, installations and infra-structure works and low impacts refer just to point damages. According to the information of the atlas, the rivers with more registered flooding events are: Guandu, Tinguá, Saracuruna and Guapimirim.

\section{CONCLUSION}

The combined vision of flooding and mobility problems poses a new issue for discussion. According to Hannam, Sheller and Urry (2006, p.1-2):

Many public, private and not-for-profit organizations are seeking to understand, monitor, manage and transform aspects of these multiple mobilities, and of the new "immobilities", social exclusions and security threats that may be associated with them. And partly as an effect a "mobility turn" is spreading into and transforming the social sciences, not only placing new issues on the table, but also transcending disciplinary boundaries and putting into question the fundamental "territorial" and "sedentary" precepts of twentieth-century social science.

In one hand, urban mobility takes the damage of urban growth. On the other hand, natural disasters like floods and flashfloods may affect the urban mobility. The information of the number of people that leave, pass through and arrive at each traffic region subdivision, together with hydrographic information, support the computation of those people whose mobility is affected during this hydrological natural disasters episodes.

Big cities all around the world are concerned about urban mobility and related projects and planning. This is an important issue for countries of late urbanization, such as Brazil. Simultaneously to population's growth, the amount of cars and other vehicles have been increasing due to higher purchasing power. Nevertheless, the Government is unable to improve urban public transportation to fit the demand. This entire context, in association to the occurrence of extreme events of precipitation, worsens urban mobility in big cities.

In Brazil there are many ongoing mobility projects in big and medium size cities, focusing on the expansion of public transportation and metro lines, monitoring of vehicles on the roads 
and creation of bicycle lanes. However, there are few studies of the impact of floods on urban mobility in a Brazilian metropolitan region and this necessity of more information and assessment specially concerns Rio de Janeiro - the second largest metropolitan region in Brazil.

This paper presented the mobility index (IFUM), a tool for analyzing the impacts of floods on urban mobility. Was represented a new tool, based on free software, which can be reproduced in other studies, as well as an important resource for urban planners and decision makers.

High direct IFUM indexes were observed for the Rivers Pavuna and Guandu Mirim. Pavuna River passes through the municipality of Rio de Janeiro and Guandu Mirim River passes through "Dutra" Road (BR 116 Road) and through Brasil Avenue (urban part of BR 101 road), therefore these two rivers should be highly considered when planning actions to mitigate flood impacts. Guapimirim River, despite its location on an area with few urban sectors, shows a high IFUM value. Floods are also frequent in Tinguá and Saracuruna Rivers. The direct IFUM index is high for Tinguá River and low for Saracuruna River.

Origin and destination data, combined to flood events data, point that the Rivers Guapimirim and Saracuruna in the MRRJ should also receive priority for investments and urban planning activities, considering their flood frequencies and possible impacts on routes intercepted by them.

The research perspectives include the analysis of other rivers in the region, and the application of the proposed index to other Brazilian regions.

It is recommended that studies like this be incorporated to urban planning projects focusing on urban mobility, to achieve a holistic diagnosis of the problems to face and to ease decision making for daily mobility and for critic moments, such as flood events.

\section{ACKNOWLEDGEMENTS}

The authors acknowledge the support of CNPq (454267/2014-2 and 402240/2012-0). 


\section{REFERENCES}

ANA. Atlas de Vulnerabilidade a Inundações no Estado do Rio de Janeiro. Superintendência de Usos Múltiplos e Eventos Críticos da Agência Nacional de Águas (ANA), 2012.

BRANDÃO, A. M. de P. M. Clima Urbano e Enchentes na Cidade do Rio de Janeiro. In: Simões, L. L.; Lino, C. F. Impactos Ambientais Urbanos no Brasil (PP.107-123). Rio de Janeiro: Ed. Bertrand Brasil, 2001.

BRASIL. Lei N 12587, de 3 de janeiro de 2012. Institui as diretrizes da Política Nacional de Mobilidade Urbana; revoga dispositivos dos Decretos-Leis $\mathrm{n}^{\mathrm{os}}$ 3.326, de 3 de junho de 1941, e 5.405, de 13 de abril de 1943, da Consolidação das Leis do Trabalho (CLT), aprovada pelo Decreto-Lei $n^{\circ}$ 5.452, de $1^{\circ}$ de maio de 1943, e das Leis $\mathrm{n}^{\circ}$ - 5.917 , de 10 de setembro de 1973, e 6.261, de 14 de novembro de 1975; e dá outras providências. Retrieved from: http://www.planalto.gov.br/ccivil 03/ ato2011-2014/2012/lei/l12587.htm. Accessed in June10th, 2013.

CEPED/UFSC. Atlas Brasileiro de Desastres Naturais 1991 a 2010: volume Brasil. Centro Universitário de Estudos e Pesquisas sobre Desastres. Universidade Federal de Santa Catarina. Florianópolis: CEPED/UFSC, 2012.

CUI, A. Bus Passenger Origin-Destination Matrix Estimation Using Automated.

Data Collection Systems (Unpublished master degree dissertation). Department of Civil and Environmental Engineering, Massachusetts Institute of Technology, 2006.

GRAY, C., MUELLER, V. Natural disasters and population mobility in Bangladesh.Proceedings of the National Academy of Sciences.Doi: 10.1073/pnas.1115944109, 2012.

GUO, D., ZHU, X., GAO, H. J. P., eAndris, C. Discovering Spatial Patterns in Origin-Destination Mobility Data.Transactions in GIS, 16, 3, 411-429, 2012.

HANNAM , K.; SHELLER, M.; URRY,J. Editorial: Mobilities, Immobilities and Moorings, Mobilities, 1:1, 1-22, 2006.

HOGAN, D. J. and MARANDOLA JR. E. Vulnerabilidade a Perigos Naturais nos Estudos de População e Ambiente In: Hogan, D. J (Org.) Dinâmica populacional e mudança ambiental: cenários para o desenvolvimento brasileiro (p.83-112) Campinas: Núcleo de Estudos de População-Nepo/Unicamp, 2007.

HUNTER, L. M. Migration and environmental hazards.Population Environmental, 26, 273302, 2005.

MARANDOLA, JR. E. Mobilidade e VulnerabilidadenosEspaços de Vida de Campinas.Paper presented at XV EncontroNacional de EstudosPopulacionais, Caxambú, MG, 2006.

NOBRE, Carlos A. Vulnerabilidades das megacidades brasileiras às mudanças climáticas: região metropolitana de São Paulo: relatório final / Carlos A. Nobre, coordenador. - São José dos Campos, SP: INPE. 192 p. ISBN 978-85-17-00067-6, 2011.

PEREIRA, R. H. M.; Schwanen. Tempo de deslocamento casa-trabalho no Brasil (1992-2009): diferenças entre regiões metropolitanas, níveis de renda e sexo.Brasília: IPEA, 2012. 
PERO, V, and MIHESSEN, V. Mobilidade urbana e pobreza no rio de janeiro. Rio de Janeiro: BNDES/ANPEC (Séries WorkingPaper BNDES/ANPEC no 46) website: http://www.ie.ufrj.br/images/pesquisa/pesquisa/textos_sem_peq/texto2105.pdf, 2012.

Programa das Nações Unidas para o Desenvolvimento - PNUD. Desenvolvimento do Guia PlanMob para orientação aos órgãos gestores municipais na elaboração dos Planos Diretores de Transporte e da Mobilidade. Secretaria Nacional de Transporte e da Mobilidade Urbana SeMob. Diretoria de Mobilidade Urbana - DEMOB. Programa das Nações Unidas para o Desenvolvimento - PNUD. Ministério das Cidades. Retrieved from: http://www.conder.ba.gov.br/ckfinder/userfiles/files/Plano\%20Mobilidade.pdf, 2007.

Programa de las Naciones Unidas para los Asentamientos Humanos (ONU-Habitat). Estado de las ciudades de América Latina y el Caribe. ISBN 978-92-1-133397-8, 2012.

QUEIROZ, L. C. R., RIBEIRO, M. G. Ibeu: índice de bem-estar urbano 1. ed. - Rio de Janeiro: Letra Capital, 2013.

SOLER, L. et al. Challenges and perspectives of innovative digital ecosystems designed to monitor and warn natural disasters in Brazil. Paper presented at ACM Conference on Management of Emergent Digital EcoSystems (ACM MEDES'13), Neumünster Abbey, Luxembourg, 2013.

TUCCI, C. E. M. Águas Urbanas. In: Tucci, C. E. M.; Bertoni,J. C. (org). Inundações urbanas na América do Sul. Porto Alegre: Associação Brasileira de Recursos Hídricos, 471 p, 2003.

UN High Commissioner for Refugees, Climate Change, Natural Disasters and Human Displacement. A UNHCR Perspective.Retrievedfrom: http://www.refworld.org/docid/4a8e4f8b2.html, 2009.

UNDP - UNITED NATIONS DEVELOPMENT PROGRAMME.Reducing disaster risk: a challengefor development.New York, USA: UNDP, 129 p., 2004.

Universidade Federal de Santa Catarina. Centro Universitário de Estudos e Pesquisas sobre Desastres. Atlas brasileiro de desastres naturais 1991 a 2010: volume Rio de Janeiro/ Centro Universitário de Estudos e Pesquisas sobre Desastres. Florianópolis. CEPED UFSC, 2011.

VEYRET, Y. (Org.) Os riscos: o homem como agressor e vítima do meio ambiente. São Paulo, SP: Contexto, 2007.

\begin{tabular}{cc} 
Artigo submetido em & 18/08/2014 \\
\hline Artigo aceito em & 21/01/2015
\end{tabular}

